Nominal: Barometer Riset Akuntansi dan Manajemen

P-ISSN: 2303-2065 E-ISSN: 2502-5430

Volume 9 No 2 (2020)

\title{
PENGARUH EARNING PER SHARE, RETURN ON ASSETS, DAN DEBT TO EQUITY RATIO TERHADAP HARGA SAHAM
}

\author{
Muhammad Fala Dika \\ Prodi Akuntansi Universitas Pembangunan Nasional Veteran Yogyakarta \\ dikafala@gmail.com \\ Hiras Pasaribu \\ Prodi Akuntansi Universitas Pembangunan Nasional Veteran Yogyakarta \\ hiras.pasaribu@upnyk.ac.id
}

\begin{abstract}
Abstrak: Pengaruh Earning Per Share, Return On Assets, dan Debt to Equity Ratio Terhadap Harga Saham. Penelitian ini berujuan, untuk mengetahui pengaruh Earning Per Share (EPS), Return On Assets (ROA), dan Debt to Equity Ratio (DER) dari, ROA terhadap harga saham. Penelitian ini dilakukan pada perusahaan industri makanan dan minuman yang terdaftar di Bursa Efek Indonesia periode tahun 2015 - 2018 sebanyak 19 perusahaan. Teknik penarikan sampel menggunakan metode purposive sampling, dengan kriteria yang ditentukan dalam penelitian ini. Sesuai kriteria penarikan sampel diperoleh sampel jumlah 13 perusahaan Metode analisis data menggunakan analisis regresi berganda. Hasil penelitian ini menunjukkan variable EPS dan ROA berpengaruh signifikan terhadap harga saham, sedangkan DER tidak berpengaruh signifikan terhadap harga saham.
\end{abstract}

Kata Kunci: EPS, ROA, DER , Harga Saham.

Abstract: The influence of Earning Per Share, Return On Assets, and Debt to Equity Ratio on Stock Price. This study aims to determine the effect of Earning Per Share (EPS), Return On Assets (ROA), and Debt to Equity Ratio (DER) of, ROA on stock prices. This research has been conducted on 19 companies in the food and beverage industry listed on the Indonesia Stock Exchange in the 2015 - 2018. The sampling technique uses a purposive sampling method, with the criteria determined in this study. As per the sampling criteria, a sample of 13 companies has been obtained. The purpose of data analysis used multiple regression analysis. The results of this study indicate that EPS and ROA variables have a significant effect on stock prices, while DER has no significant impact on stock prices.

Keywords: EPS, ROA, DER, Stock Price.

\section{PENDAHULUAN}

Harga saham merupakan salah satu indikator penting bagi investor untuk menilai keberhasilan pengelolaan perusahaan masa yang akan datang (Efendi \& Ngatno, 2018). Jika harga saham suatu perusahaan selalu mengalami kenaikan, maka investor atau calon investor menilai bahwa peruasahaan berhasil dalam mengelola usahanya. (Efendi \& Ngatno,
2018) mendefinisikan harga pasar saham adalah harga jual dari investor yang satu kepada investor yang lain setelah saham tersebut dicantumkan di bursa. Kepercayaan investor atau calon investor sangat bermanfaat bagi perusahaan, karena semakin banyak orang yang percaya terhadap perusahaan maka keinginan untuk berinvestasi pada perusahaan akan semakin kuat. Semakin banyak permintaan terhadap 


\section{Nominal: Barometer Riset Akuntansi dan Manajemen \\ P-ISSN: 2303-2065 E-ISSN: 2502-5430 \\ Volume 9 No 2 (2020)}

saham suatu perusahaan, maka dapat menaikkan harga saham perusahaan tersebut. Jika harga saham yang tinggi dapat dipertahankan maka kepercayaan investor atau calon investor terhadap perusahaan juga semakin tinggi dan hal ini dapat menaikkan nilai perusahaan. Sebaliknya, jika harga saham mengalami penurunan secara terus menerus maka dapat menurunkan nilai perusahaan dimata investor atau calon investor.

Perkembangan dunia industri saat ini berjalan dengan begitu pesat sehingga menciptakan persaingan yang semakin ketat, para pelaku bisnis pun dituntut untuk lebih kreatif dan memiliki keunggulan kompetitif dibanding dengan para pesaingnya. Industri makanan dan minuman merupakan salah satu dari sekian banyak industri yang mengalami persaingan yang sangat ketat, hal ini dapat ditunjukkan dengan semakin banyaknya pelaku usaha yang memasuki sektor industri ini. Sektor industri barang konsumsi sendiri adalah sebuah industri yang bergerak dalam memproduksi kebutuhan masyarakat berupa makanan dan minuman sebagai kebutuhan pokok seharihari.

Seperti yang dinyatakan oleh Kementerian Perindustrian (Sumber www. kemeperin.go.id diposting 18 Februari 2019, diakses 22 Februari 2020) mencatat, bahwasannya sepanjang tahun 2018, industri sektor makanan dan minuman mampu tumbuh sebesar $7,91 \%$ atau melampaui pertumbuhan ekonomi nasional di angka 5,17\%. Bahkan, pertumbuhan produksi industri manufaktur besar dan sedang di triwulan IV-2018 naik sebesar $3,90 \%(y-o n-y)$ terhadap triwulan IV-2017, salah satunya disebabkan oleh meningkatnya produksi industri minuman yang mencapai 23,44\%. Selanjutnya, industri makanan dan minuman menjadi salah satu sektor yang menopang peningkatkan nilai investasi nasional, yang pada tahun 2018 menyumbang hingga Rp56,60 triliun. Realisasi total nilai investasi di sektor industri manufaktur sepanjang tahun lalu mencapai $\mathrm{Rp} 222,3$ triliun. Fenomena tersebut juga tak lepas dari peran investor, yang sudah menanamkan modalnya di perusahaan makanan dan minuman. Fenomena tersebut diperkuat dengan tercapainya perusahaa makanan dan minuman menjadi favorit investor versi Kemenperin tahun 2015.

Penelitian-penelitian yang pernah dilakukan sebelumnya mengenai faktorfaktor yang memengaruhi harga saham di Bursa Efek Indonesia antara lain penelitian yang dilakukan oleh (Datu \& Maredesa, 2017) melakukan penelitian tentang pengaruh Earning Per Share (EPS) terhadap harga saham. Penelitian ini 


\section{Nominal: Barometer Riset Akuntansi dan Manajemen}

P-ISSN: 2303-2065 E-ISSN: 2502-5430

Volume 9 No 2 (2020)

bertujuan membuktikan pengaruh Earning Per Share (EPS) terhadap harga saham karena beberapa penelitian terdahulu menunjukkan hasil yang berbeda. Hasil penelitian tersebut sesuai dengan penelitian yang dilakukan oleh (Winda Tristanti \& Sari Marliani, 2019) yang menunjukkan bahwa EPS berpengaruh terhadap harga saham. Namun demikian hasil dari penelitian (Putra \& Kindangen, 2016) tidak menunjukkan adana pengauh EPS terhadap harga saham.

Return on Assets (ROA) menunjukkan kemampuan perusahaan menghasilkan keuntungan atau laba dari aktiva yang dipergunakan (Efendi \& Ngatno, 2018). Apabila rasio ini menunjukkan ukuran yang lebih baik atas profitabilitas perusahaan, maka aktiva yang dioperasionalkan akan menunjukkan efektifitas manajemen dalam menggunakan aktiva untuk memperoleh keuntungan atau laba. Semakin tinggi ROA maka semakin tinggi pula kemampuan perusahaan untuk menghasilkan keuntungan. ROA yang tinggi akan menarik investor untuk menanamkan modalnya kepada perusahaan. Hal ini karena dianggap berhasil menghasilkan laba yang tinggi dan berdampak pada deviden yang akan diterima oleh investor.

Pada Variabel lain (Setyorini, Maria, 2016) melakukan penelitian tentang Return
On Asset (ROA) terhadap harga saham. Penelitian ini bertujuan untuk membuktikan pengaruh Return On Asset (ROA) terhadap harga saham. Penelitian ini menunjukkan bahwa ROA berpengaruh terhadap harga saham. Akan tetapi, penelitian yang dilakukan oleh (Meyer et al., 1970) menunjukkan bahwa ROA tidak berpengaruh terhadap harga saham.

Debt to Equity Ratio (DER) adalah rasio untuk mengukur kemampuan perusahaan dalam menutup sebagian atau seluruh hutangnya, dengan dana yang berasal dari dana sendiri perusahaan. Dengan kata lain, rasio ini mengukur seberapa besar total pasiva yang terdiri atas presentase modal perusahaan sendiri dibandingkan dengan besarnya hutang yang dimiliki masing-masing perusahaan.

Besarnya rasio ini, menunjukkan proporsi modal perusahaan yang diperoleh dari hutang dibandingkan dengan sumbersumber modal lain seperti saham preferen, saham biasa atau laba yang ditahan. Semakin tinggi proporsi DER, menyebabkan laba perusahaan semakin tidak menentu dan menambah kemungkinan bahwa perusahaan tidak dapat memenuhi kewajiban pembayaran hutangnya (Setyorini, Maria, 2016). Oleh karena itu, semakin tinggi proporsi rasio hutang akan semakin tinggi pula risiko Financial suatu perusahaan. Tinggi 


\section{Nominal: Barometer Riset Akuntansi dan Manajemen \\ P-ISSN: 2303-2065 E-ISSN: 2502-5430 \\ Volume 9 No 2 (2020)}

rendahnya risiko keuangan perusahaan secara tidak langsung dapat memengaruhi harga saham perusahaan tersebut. Maka, perusahaan dengan DER yang rendah akan lebih diminati oleh para calon investor karena risiko keuangannya yang lebih sedikit.

Berdasarkan fenomena dan uraian diatas, masih ada kesenjangan hasil pada peneliti-peneliti terdahulu. Maka disini peneliti tertarik untuk melakukan penelitian kembali mengenai faktor-faktor yang memengaruhi harga saham pada perusahaan makanan dan minuman yang terdaftar di BEI tahun 2015-2018.

\section{KAJIAN LITERATUR}

\section{Pengertian Pasar Modal}

Pasar modal merupakan kegiatan yang bersangkutan dengan penawaran umum dan perdagangan efek, perusahaan publik yang berkaitan dengan efek yang diterbitkannya, serta lembaga dan profesi yang berkaitan dengan efek. Efek adalah surat berharga, yaitu surat pengakuan hutang, surat berharga komersial, saham, obligasi, tanda bukti hutang, unit penyertaan investasi kolektif, kontrak berjangka atas efek, dan setiap derivatif dari efek (Presiden Republik Indonesia, 1995). Sedangkan menurut (Undang-Undang Republik Indonesia Nomor 21 Tahun 2008 Tentang Perbankan Syariah, 2008), pasar modal adalah kegiatan yang bersangkutan dengan Penawaran Umum dan perdagangan efek, perusahaan publik yang berkaitan dengan efek yang diterbitkannya, serta lembaga dan profesi yang berkaitan dengan efek sebagaimana dimaksud dalam undang-undang mengenai pasar modal.

\section{Pengertian Harga Saham}

Harga saham adalah harga pasar atau sekuritas saham yang terjadi karena adanya interaksi antara permintaan dan penawaran pasar, yang secara dasar ditentukan oleh aktiva yang diwakilinya (Adi \& Lesmana, 2017). Pada pasar yang efisien, harga saham berubah berdasarkan informasi yang ada (Datu \& Maredesa, 2017). Dalam persaingan pasar seperti di Bursa Efek Indonesia interaksi yang terjadi antara pembeli dan penjual menghasilkan harga pada tingkat keseimbangan (equilibrium price) atau yang biasa disebut juga dengan istilah market value. Harga pasar saham yang aktif diperdagangkan dapat dilihat di surat kabar. Harga penutupan (closing price) menunjukkan harga pasar saham (market value) pada akhir hari diperdagangkan. Menurut (Winda Tristanti \& Sari Marliani, 2019) perubahan harga saham dapat dilihat di sekitar tanggal exdividend, yang menyatakan harga saham suatu perusahaanakan turun sebesar dividen yang dibagikan. Tapi para spekulan akan membeli saham sehari sebelum tanggal ex- 


\section{Nominal: Barometer Riset Akuntansi dan Manajemen \\ P-ISSN: 2303-2065 E-ISSN: 2502-5430 \\ Volume 9 No 2 (2020)}

dividend dan menjual pada tanggal exdividend dengan harapan harga saham setelah tanggal ex-dividend tidak turun, sehingga spekulan tersebut akan menerima dividen dan capital gain. Selanjutnya (Adi \& Lesmana, 2017) dalam Signalling Theory, mengemukakan mengenai sinyal yang diberikan perusahaan melalui laporan keuangan meliputi analisis rasio-rasio keuangannya, seperti ROA dan EPS untuk mempengaruhi keputusan investor dalam berinvestasi.

\section{EPS (Earning Per Share)}

Dapat dikatakan, bahwasannya EPS merupakan laba yang akan diterima oleh investor atas setiap lembar saham yang ia belikan. EPS merupakan perbandingan antara laba bersih setelah pajak pada suatu tahun buku dengan jumlah saham yang diterbitkan (Datu \& Maredesa, 2017). Di dalam perhitungan EPS, terdapat dua jenis EPS, yaitu :

A. EPS Historis yaitu EPS yang dihitung berdasarkan kinerja perusahaan pada tahun buku yang telah lampau. EPS historis merupakan nilai yang telah terjadi pada masa lampau.

B. EPS Proyektif EPS yang diperkirakan akan terjadi dengan asumsi sesuai dengan proyeksi kinerja emiten.

Earning Per Share (EPS) menyatakan bahwasannya para penanam modal (investor) sering menggunakan istilah income stock and growth stock (Winda Tristanti \& Sari Marliani, 2019). Mereka kelihatannya membeli saham yang sedang tumbuh terutama dengan pengharapan memperoleh keuntungan modal dan mereka lebih berminat pada pertumbuhan pendapatan pada masa mendatang daripada dalam dividen tahun berikutnya. Sebaliknya mereka membeli incomestock terutama untuk memperoleh dividen tunai.

Rumus EPS (Earning Per Share) menurut (Watung \& Ilat, 2016) adalah sebagai berikut :

$\mathrm{EPS}=\frac{E A T}{\text { Jumlah Lembar Saham }}$

\section{ROA (Retutn On Asset)}

Return On Asset menunjukkan kemampuan perusahaan dalam menghasilkan laba dari aktiva yang dipergunakan, juga merupakan rasio laba bersih terhadap total aktiva yang digunakan untuk mengukur pengembalian atas total aktiva setelah bunga dan pajak. ROA adalah rasio yang menunjukkan kemampuan perusahaan menghasilkan laba bersih bagi semua investor dari modal yang diinvestasikan dalam keseluruhan aktiva (Asri, 2017). Lebih lanjut (Suhadi, 2019) menyatakan rate of return on assets adalah kemampuan dari modal yang diinvestasikan dalam keseluruhan aktiva 


\section{Nominal: Barometer Riset Akuntansi dan Manajemen \\ P-ISSN: 2303-2065 E-ISSN: 2502-5430 \\ Volume 9 No 2 (2020)}

untuk mengasilkan keuntungan bagi semua investor (pemegang obligasi saham). Rendahnya pengembalian basic earning point (BEP) perusahaan dan tingginya biaya bunga karena penggunaan kewajiban di atas rata-rata yang menyebabkan laba bersih relatif rendah.

Rumus ROA (Return On Asset) menurut (Watung \& Ilat, 2016) adalah sebagai berikut :

$\mathrm{ROA}=\frac{E A T}{\text { Total } \text { Asset }}$

\section{DER (Debt to Equity Ratio)}

Menurut (Nurfadillah, 2011), DER adalah perbandingan atau rasio antara utang terhadap ekuitas. Rasio ini menunjukkan risiko perusahaan, dimana semakin rendah DER mencerminkan semakin besar kemampuan perusahaan dalam menjamin utangnya dengan ekuitas yang dimiliki. Besarnya rasio ini menunjukkan besarnya modal perusahaan yang diperoleh dari utang dibandingkan dengan sumbersumber modal yang lainnya, seperti saham preferen, saham biasa atau laba yang ditahan. Semakin tinggi proporsi DER, maka menyebabkan laba perusahaan semakin tidak menentu dan menambah kemungkinan bahwa perusahaan tidak dapat memenuhi kewajiban pembayaran utangnya. Oleh karena itu, semakin tinggi proporsi rasio utang akan semakin tinggi pula risiko keunagan suatu perusahaan.
Tinggi rendahnya risiko keuangan perusahaan secara tidak langsung dapat memengaruhi harga saham perusahaan tersebut.

Rumus DER (Debt to Equity Rstio) menurut (Dewi, 2018) adalah sebagai berikut :

DER $=\frac{\text { Total } \text { Hutang }}{\text { Total } \text { Ekuitas }}$

\section{Kerangka Konseptual}

Berikut ini adalah kerangka pemikiran teoritis dalam penelitian ini:

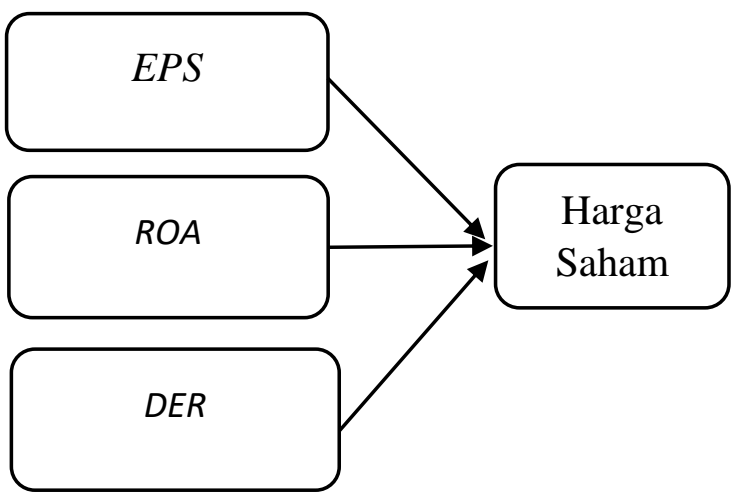

Gambar 1: Kerangka Konseptual

Berdasarkan kerangka konseptual di atas, maka dapat dinyatakan hipotesis penelitian sebagai berikut: H1 : EPS berpengaruh signifkan terhadap pengungkapan harga saham $\mathrm{H} 2$ : ROA berpengaruh signifkan terhadap pengungkapan harga saham H3 : DER berpengaruh signifkan terhadap pengungkapan harga saham

\section{METODE PENELITIAN}

Penelitian ini akan dilakukan dengan menguji pengaruh antara variable-variabel 


\section{Nominal: Barometer Riset Akuntansi dan Manajemen}

P-ISSN: 2303-2065 E-ISSN: 2502-5430

Volume 9 No 2 (2020)

bebas terhadap variable terkait. Desain penelitian ini adalah desain penelitian kuantitatif. Desain penelitian kuantitatif, merupakan penelitian yang dilakukan oleh seseorang untuk menguji hipotesishipotesis yang sudah dirumuskan sebelumnya oleh peneliti dan kemudian membuat analisis perhitungan berdasarkan data-data yang diperoleh dari berbagai sumber. Diharapkan dengan menggunakan desain penelitian ini, didapatkan pengaruh Earning Per Share (EPS), Return On Asset (ROA), dan Debt to Equity Ratio (DER) terhadap harga saham perusahaan makanan dan minuman yang terdaftar di BEI.

Untuk memperoleh data sekunder tersebut peneliti melakukan studi pustaka dan dokumentasi terhadap data-data yang berkaitan dengan permasalahan penelitian. Jenis data yang digunakan dalam penelitian ini adalah data sekunder dalam bentuk timeseries (data runtut waktu). Data yang akan digunakan diperoleh dari laporan perusahaan yang di publish di website masing-masing perusahaan maupun di www.idx.co.id.

\section{Populasi}

Populasi yang digunakan pada penelitian ini adalah berjumlah 19 perusahaan makanan dan minuman yang terdaftar di Bursa Efek Indonesia (BEI) pada tahun 2015 sampai dengan 2018. Data yang diperlukan dalam penelitian ini berupa laporan keuangan perusahaan makanan dan minuman yang terdaftar di Bursa Efek Indonesia (BEI) tahun 2015 sampai dengan 2018. Sumber data dari situs publikasi Indonesia Stock Exchange (IDX), Indonesia Capital Market Directory (ICMD) dan sumber lainnya. Aapabila data yang diambil terdapat beberapa masalah maka peneliti akan melakukan pengecekan ulang data ke annual report dan laporan publikasi perusahaan yang terdapat di website Bursa Efek Indonesia (BEI).

\section{Sampel Penelitian}

Sampel yang diambil harus representative terhadap populasi. Teknik pengambilan sampel yang digunakan dalam penelitian ini adalah metode purposive sampling, yaitu pengambilan sampel berdasarkan kriteria

tertentu sesuai dengan yang dikehendaki oleh peneliti.

Sampel dalam penelitian ini berjumlah 13 perusahaan yang diperoleh dengan menggunakan teknik purposive sampling. Dengan karakteristik sampel sebagai berikut:

1) Perusahaan makanan dan minuman yang terdaftar di Bursa Efek Indonesia (BEI) dari tahun 2015 sampai dengan 2018 yang telah menerbitkan laporan keuangannya 4 tahun berturut-turut. 
2) Perusahaan yang menghasilkan laba (profit) positif secara 4 tahun berturut-turut.

3) Penelitian ini menggunakan data publikasi laporan keuangan tahun 2015 sampai dengan 2018 sesuai dengan yang dibutuhkan, baik data mengenai Earning Per Share (EPS), Return On Asset (ROA), Debt To Equity Ratio (DER), dan harga saham.

\section{Model dan Teknik Analisis Data}

Metode analisis yang digunakan dalam penelitian ini adalah analisis regresi linear berganda. Analisis regresi linier berganda adalah hubungan secara linear antara dua atau lebih variabel independen dengan satu variabel dependen yang digunakan untuk memprediksi atau meramalkan suatu nilai variabel dependen berdasarkan variabel independent (Priyatno, 2016). Model analisis regresi linear berganda dinyatakan dengan persamaan sebagai berikut :

$$
\mathrm{Y}=\mathrm{a}+b_{1} X_{1}+b_{2} X_{2}+b_{3} X_{3}+\epsilon
$$

Keterangan:

$$
\begin{array}{cl}
\text { Y } & : \text { Harga Saham (Closing } \\
\text { Price) } & \\
\text { a } & : \text { Konstanta } \\
b_{1-3} & : \text { Koefisien Regresi } \\
X_{1} & : \text { Earning Per Share (EPS) } \\
X_{2} & : \text { Return On Asset (ROA) }
\end{array}
$$

$$
\begin{array}{ll}
X_{3} & : \text { Debt to Eqity Ratio (DER) } \\
\in & : \text { Random Error }
\end{array}
$$

Dalam menganalisis data penelitian ini, menggunakan dua model pengujian, yaitu:

\section{1) Uji Asumsi Klasik}

Pengujian ini dilakukan untuk menguji bahwa asumsi-asumsi yang melekat pada model regresi yang dihasilkan terpenuhi sehingga sifat dari regersi yang BLUES (Best Linear Unbiased Estimator) dapat tercapai. Pengujian asumsi klasik yang dilakukan meliputi:

a) Uji Multikolinearitas

Multikolinearitas adalah keadaan dimana ada hubungan linear secara sempurna atau mendekati sempurna antara variabel independen dalam model regresi. Model regresi yang baik adalah yang terbebas dari masalah multikolinearitas. Konsekuensi adanya multikolinearitas adalah koefisien korelasi tidak tertentu dan kesalahan menjadi sangat besar atau tidak terhingga.

Variabel yang menyebabkan multikolinearitas dapat dilihat dari nilai tolerance yang lebih kecil dari 0,1 atau nilai VIF yang lebih besar dari nilai 10 (Duwi, 2011:93). Maka, jika dari output regresi didapatkan nilai tolerance lebih dari 0,1 dan 
VIF jurang dari 10, sehingga tidak terjadi multikolinearitas.

\section{b) Uji Heterokedastisitas}

Heteroskedastisitas adalah varian residual yang tidak sama pada semua pengamatan di dalam model regresi. Uji heteroskedastisitas dalam penelitian ini menggunakan Rank Spearman. Pengambilan keputusannya yaitu :

1. Jika nilai signifikansi atau Sig. (2tailed) lebih besar dari nilai 0,05 maka dapat dikatakan bahwa tidak terjadi gejala heteroskedastisitas.

2. Jika nilai signifikansi atau Sig. (2tailed) lebih kecil dari nilai 0,05 maka dapat dikatakan bahwa terjadi gejala heteroskedastisitas.

\section{c) Uji Autokorelasi}

Autokorelasi adalah hubungan yang terjadi antara residual dari pengamatan satu dengan pengamatan yang lainnya. Model regresi yang baik seharusnya tidak terjadi autokorelasi. Untuk mendeteksi ada atau tidaknya autokorelasi, maka nilai DW akan dibandingkan dengan DW table. Kriterianya adalah:

1. Jika DW $<\mathrm{dL}$ atau $\mathrm{DW}>4$-dL, berarti terdapat autokorelasi.

2. Jika DW terletak diantara dU dan 4dU berarti tidak ada autokorelasi.

3. Jika DW terletak diantara dL dan dU atau diantara 4-dU dan 4-dL, maka tidak menghasilkan kesimpulan yang pasti.

d) Uji Normalitas

Normalitas data merupakan syarat pokok yang harus dipenuhi dalam analisis parametik. Untuk yang menggunkan analisis parametik seperti analisis perbandingan 2 rata-rata, variansi satu arah, korelasi, regresi, dan sebagainya. Maka perlu dilakukan uji normalitas terlebih dahulu. Hal ini bertujuan untuk mengetahui apakah data tersebut berdistribusi normal atau tidak.

Normalitas suatu data penting, karena dengan data yang terdistribusi normal, maka data tersebut dianggap dapat mewakili suatu populasi. Dalam penelitian ini, peneliti menggunakan dasar pengambilan keputusan dengan uji normalitas kolmogorv-smirnov, yang disajikan dengan bentuk tabel.

\section{2) Uji Hipotesis}

Hpotesis adalah pernyataan mengenai sesuatu hal yang harus diuji kebenarannya. Berikut cara analisis untuk menguji hipotesis:

a) Koefisien Determinasi

Pengujian ini menjelaskan seberapa besar perilaku dari variabel independen mampu menjelaskan perilaku/variasi dari variabel dependen. Pengukuran ini menjelaskan goodness of fit dari model 


\section{Nominal: Barometer Riset Akuntansi dan Manajemen}

P-ISSN: 2303-2065 E-ISSN: 2502-5430

Volume 9 No 2 (2020)

dimana semakin mendekati nilai 1 maka model semakin goodness of fit sementara semantara semakin mendekati 0 maka model semakin tidak goodness of fit.

\section{b) Uji F}

Uji $F$ digunakan untuk mengetahui pengaruh secara bersama-sama antara variable independen terhadap variable dependen. Uji $\mathrm{F}$ merupakan pengujian hubungan regresi secara simultan dari variabel-variabel dependen yang bertujuan untuk menguji apakah secara bersamasama seluruh variabel independen mempunyai pengaruh yang signifikan

terhadap variable dependennya. Jika nilai sig $<0,05$ maka variabel independen secara bersama- sama atau simultan berpengaruh terhadap variabel dependen.

c) Uji t

Pengujian ini dilakukan untuk menguji apakah secara individu (masingmasing) variabel independen mempunyai pengaruh yang signifikan terhadap variable dependennya. Uji-t test adalah pengujian koefisien regresi masng-masing variable independen terhadap variable dependen untuk mengetahui seberapa besar pengaruh variable independent terhadap variabel dependen. Hasil pengujian uji t ini dapat dilakukan dengan cara membandingkan antara $t$ hitung dengan $t$ tabel atau dengan cara membandingkan probabilitas dari $\mathrm{t}$ hitung dengan alpha 5\%, dengan ketentuan jika nilai sig. $<0,05$ maka artinya variabel independen (X) secara parsial berpengaruh terhadap variabel dependen (Y).

\section{HASIL PENELITIAN DAN}

\section{PEMBAHASAN}

\section{Penyajian Data Penelitian}

Berdasarkan tabel 1, perusahaan yang menerbitkan annual report pada tahun 2015-2018 yang terdaftar di BEI sebanyak 19 perusahaan. Perusahaan yang tidak memenuhi kriteria purposive sampling sebanyak 6 perusahaan. Maka didapatkan observasi penelitian sebanyak 13 x 4 tahun $=52$ observasi penelitian.

Tabel 1: Kriteria Pemilihan Sampel Penelitian

\begin{tabular}{clc}
\hline No & \multicolumn{1}{c}{ Keterangan } & Jumlah \\
\hline 1. & $\begin{array}{l}\text { Perusahaan makanan dan } \\
\text { minuman yang terdaftar di }\end{array}$ & 19 \\
& $\begin{array}{l}\text { BEI di tahun 2015 sampai } \\
\text { dengan tahun 2018. }\end{array}$ \\
2. & $\begin{array}{l}\text { Perusahaan yang } \\
\text { mencatatkan kerugian. }\end{array}$ \\
3. & $\begin{array}{l}\text { Perusahaan yang tidak } \\
\text { menerbitkan laporan } \\
\text { keuangan tahunan 4 tahun } \\
\text { berturut-turut. }\end{array}$ \\
Jumlah perusahaan sampel & $\mathbf{1 3}$ \\
\hline
\end{tabular}

\section{Analisis Statistik Deskriptif}

Tabel 2 : Analisis Statistik Deskriptif

\begin{tabular}{cccc}
\hline & \multicolumn{3}{c}{ Descriptive Statistics } \\
N & Min & Max \\
\hline EPS & 52 & 4,69 & 2082,66 \\
ROA & 52 &, 01 &, 53 \\
DER & 52 &, 16 & 1,95 \\
Harga & 52 & 63 & 30500 \\
Saham & & & \\
\hline
\end{tabular}


Tabel 2 memberikan gambaran tentang jumlah pengamatan, maksimum, minimum pada perusahaan-perusahaan sampel. Jumlah pengamatan dalam penelitian yaitu 52 observasi. Variabel EPS memiliki milai minimum sebesar 4,69, yaitu data milik PT Budi Strach \& Sweetener pada tahun 2015. Nilai maksimum sebesar 2082,66, yaitu data milik PT Mayora Indah Tbk pada tahu 2015 dengan rata-rata 236,7862, dan simpangan baku sebesar 321,21333. Variabel ROA memiliki nilai minimum sebesar 0,01, yaitu pada perusahaan PT Budi Strach \& Sweetener tahun 2015. Nilai maksimum sebesar 0,53 yaitu data milik PT Multi Bintang Indonesia Tbk pada tahun 2017, dengan rata-rata sebesar 0,1146 dan simpangan baku sebesar 0,10678. Variabel DER memiliki nilai minimum sebesar 0,16 , yaitu data milik PT Ultra Jaya Milk Industry pada tahun 2018. Nilai maksimum sebesar 1,95 dengan rata-rata 0,9050 pada PT Budi Strach \& Sweetener Tbk dan simpangan baku sebesar 0,48339. Variabel harga saham, sebagai variabel dependen memiliki nilai minimum sebesar 63 yaitu data milik PT Budi Strach \& Sweetener tahun 2015. Nilai maksimum sebesar 30500 yaitu data milik PT Mayora Indah Tbk pada tahun 2015, dengan rata-rata 4281,31 dan simpangan baku sebesar 5444,404.
Model regresi berdistribusi normal jika nilai dari signifikansi $>0,05$. Berdasarkan tabel 3, bahwasanya nilai dari Asym. Sig. (2-tailed) > 0,05. Maka data pada penelitian ini berdistribusi dengan normal atau dengan kata lain memenuhi asumsi normalitas.

Tabel 3 : Uji Normalitas One Sample Kolmogorov-Smirnov Test

Asymp. Sig. (2-tailed) , 200

\section{Uji Multikolinearitas}

Tabel 4 : Uji Multikolinearitas

\begin{tabular}{|c|c|c|c|}
\hline \multicolumn{2}{|c|}{ Variable Tolerance VIF } & $\begin{array}{l}\text { VIF } \\
\text { Hitung }\end{array}$ & Kesimpulan \\
\hline EPS & ,841 & 1,189 & $\begin{array}{l}\text { Non } \\
\text { multikolinearitas }\end{array}$ \\
\hline ROA & ,841 & 1,189 & $\begin{array}{l}\text { Non } \\
\text { multikolinearitas }\end{array}$ \\
\hline DER & 1,000 & 1,000 & $\begin{array}{l}\text { Non } \\
\text { multikolinearitas }\end{array}$ \\
\hline arg & & & \\
\hline
\end{tabular}

Tidak terjadi gejala multikolinearitas, jika nilai tolerance $>$ dari 0,100 dan nilai VIF (variance inflation factor) $<10,00$. Berdasarkan tabel 4 diatas, nilai tolerance dari EPS sebesar 0,841. Nilai tolerance dari ROA sebesar 0,841 dan nilai tolerance dari DER sebesar 1,000. Berdasarkan angka tersebut maka seluruh variabel mempunyai nilai diatas 0,100 .

Nilai VIF variabel EPS yaitu sebesar 1,189, variabel ROA sebesar 1,189 dan variabel DER sebesar 1,000. Berdasarkan

\section{Uji Normalitas}


angka tersebut maka nilai VIF seluruh variabel dibawah 10,00.

Berdasarkan dasar pengambilan keputusan serta uraian diatas, maka data pada penelitian ini lolos dari uji multikolinearitas atau dengan kata lain data penelitian ini tidak ada gejala multikolinearitas.

\section{Uji Heteroskedastisitas}

Tidak terjadi heteroskedastisitas jika nilai Sig. (2-tailed) $>0,05$. Berdasarkan tabel 5 nilai Sig. (2-tailed) $>0,05$. Maka berdasarkan dasar pengambilan keputusan tersebut dan tabel diatas, maka data penelitian ini lolos uji heteroskedastisitas atau dengan kata lain tidak ada gejala heteroskedastisitas.

Tabel 5: Uji Heteroskedastisitas

\begin{tabular}{ll}
\hline Variable & Sig-2 (tailed) \\
\hline EPS &, 188 \\
ROA &, 256 \\
DER &, 922
\end{tabular}

Harga Saham

\section{Uji Autokorelasi}

Tidak ada gejala autokorelasi jika nilai dari Durbin Watson terletak diantara dU sampai dengan (4-dU). Nilai dU diperoleh dari tabel distribusi durbin Watson, berdasarkan $\mathrm{K}$ (jumlah variabel) dan $\mathrm{N}$ (jumlah data) pada signifikansi 5\%.
Dengan $\mathrm{K}=3$, serta $\mathrm{N}=52$ maka dapat diperoleh dari tabel durbin Watson sebesar 1,676. Hasil dari (4-dU) adalah 2.324. Dengan dasar pengambilan keputusan seperti diatas, maka diperoleh du $(1,676)<$ Durbin Watson $(2,221)<4$-dU $(2,324)$. Berdasarkan hasil tersebut maka data penelitian ini tidak ada gejala autokorelasi.

Tabel 6: Uji Autokorelasi

\begin{tabular}{cc}
\hline \multicolumn{2}{c}{ Model Summary } \\
\hline Durbin Watson 2,221 \\
\hline
\end{tabular}

\section{Koefisien Determinasi}

Koefisien determinasi (R Square) merupakan representasi dari kemampuan model dalam menjelaskan variasi variabel dependen. Berdasarkan tabel 7 nilai RSquare yang diperoleh sebesar 0.888 . Menunjukkan bahwa sebesar 88,8\% variasi dari harga saham yang mampu dijelaskan oleh variabel independen, sedangkan sisanya sebesar $11,2 \%$ dijelaskan oleh variabel lain di luar model. Hal ini menunjukkan bahwa variabel EPS (Earning Per Share), ROA (Return On Asset) dan DER (Debt to Equity Ratio) sebagai variabel independen memengaruhi variabel nilai perusahaan sebesar $88,8 \%$ dan sisanya sebesar $11,2 \%$ dijelaskan oleh variabel lain diluar model.

Tabel 7: Koefisien Determinasi

Model Summary

R Square ,888 


\section{Uji F}

Jika nilai sig. $<0,05$ maka variabel independen secara simultan berpengaruh terhadap variabel dependen. Tabel 4.9 diatas menunjukkan hasil sig sebesar 0,000. Yang artinya sesuai dengan dasar pengambilan keputusan yaitu sig $<0,05$ maka dengan ini seluruh variabel yang terdiri dari EPS (Earning Per Share), ROA (Return On Asset) dan DER (Debt to Equity Ratio) secara bersama-sama berpengaruh terhadap harga saham.

Jadi dapat disimpulkan bahwa variabel independen yang terdiri dari EPS (Earning Per Share), ROA (Return On Asset) dan DER (Debt to Equity Ratio) memenuhi asumsi kelayakan model dan secara simultan berpengaruh terhadap harga saham sebagai variabel dependen.

Tabel 8 : Uji F

\begin{tabular}{lc}
\hline & ANOVA \\
\hline Sig &, $000^{\mathrm{a}}$ \\
\hline
\end{tabular}

Uji t

Jika nilai sig. $<0,05$ maka variabel independen secara parsial berpengaruh terhadap variabel dependen. Tabel diatas membuktikan bahwa nilai signifikansi (Sig.) EPS (Earning Per Share) sebesar $0,000<0,05$. Hal tersebut dapat diartikan bahwa variabel EPS (Earning Per Share) berpengaruh terhadap harga saham. Dengan demikian dapat disimpulkan bahwa hipotesis pertama (H1) yang menyatakan bahwa EPS (Earning Per Share) berpengaruh signifikan terhadap harga saham dinyatakan diterima.

Berdasarkan penjelasan diatas, hasil ini menunjukkan bahwa pada perusahaan makanan dan minuman, nilai dari EPS (Earning Per Share) sebagai kabar gembira atau good news. Nilai dari EPS (Earning Per Share) yang tercermin dalam laporan keuangan menunjukkan besarnya pendapatan per lembar saham yang akan diterima oleh para investor. Semakin tinggi nilai EPS (Earning Per Share) maka akan semakin tinggi pula pendapatan yang akan diterima oleh investor. Dengan adanya EPS (Earning Per Share) yang tinggi, maka akan mendorong perusahaan untuk membagikan dividen, sehingga investor semakin percaya bahwa perusahaan mampu memenuhi return yang diharapkan oleh para investor. Akan tetapi, jika suatu perusahaan mengasilkan EPS (Earning Per Share) yang kecil, maka kemungkinan investor itu mendapatkan dividen akan semakin kecil pula. Maka dari itu, calon investor tentu saja akan lebih tertarik menanamkan modalnya pada perusahaan yang nilai EPS (Earning Per Share) relativ lebih besar. Hal tersebut juga berguna meningkatkan kepercayaan dari para investor membantu perusahaan dalam 


\section{Nominal: Barometer Riset Akuntansi dan Manajemen \\ P-ISSN: 2303-2065 E-ISSN: 2502-5430 \\ Volume 9 No 2 (2020)}

menawarkan sahamnya, karena akan terjadi peningkatan terhadap jumlah saham perusahaan tersebut.

Tabel 9: Uji t

\begin{tabular}{ll}
\hline Variable & Sig. \\
\hline EPS &, 000 \\
ROA &, 000 \\
DER &, 358 \\
Harga Saham & \\
\hline
\end{tabular}

Dalam tabel 9 diatas juga menyajikan nilai signifikansi (Sig.) dari variabel ROA (Return On Asset) sebesar 0,000. Yang berarti memenuhi dasar pengambilan keputusan, yakni nilai signifikansi sebesar $0,000<0,05$. Hal tersebut dapat diartikan bahwa variabel ROA (Return On Asset) berpengaruh terhadap harga saham. Dengan demikian dapat disimpulkan bahwa hipotesis kedua (H2) yang menyatakan bahwa ROA (Return On Asset) berpengaruh signifikan terhadap harga saham diterima.

ROA (Return On Asset) diartikan sebagai mana kemampuan perusahaan dalam menghasilkan laba bersih dari total asset yang dimiliki. Hal tersebut berarti, dengan asset-asset yang dimiliki perusahaan, perusahaan mampu memanfaatkan asset-assetnya dengan baik, sehingga bisa menghasilkan keuntungan bagi perusahaan, karena apabila perusahaan tidak mampu menghasilkan keuntungan maka sudah jelas bahwasannya perusahaan tersebut bukanlah tempat yang layak untuk melakukan investasi. Terlebih lagi, jika perusahaan tersebut mempunyai trend yang bagus mengenai ROA (Return On Asset) ini, maka juga bisa dipastikan perusahaan tersebut layak untuk menjadi tempat berinvestasi. Jika perusahaan mampu memaksimalkan keuntungan, maka akan juga berpengaruh terhadap EAT (Earning After Tax) yang membuat EPS (Earning Per Share) juga akan ikut naik, maka harga saham perusahaan juga ikut naik.

Selain itu tabel tersebut juga menyajikan hasil uji pengaruh pada variabel independen ketiga yaitu DER (Debt to Equity Ratio) terhadap harga saham. Nilai signifikansi (Sig.) variabel DER (Debt to Equity Ratio) pada tabel tersebut sebesar 0,358 >0,05. Nilai tersebut dapat diartikan bahwa variabel DER (Debt to Equity Ratio) tidak berpengaruh terhadap harga saham. Dengan demikian dapat ditarik kesimpulan bahwa hipotesis ketiga $\left(\mathrm{H}_{3}\right)$ yang menyatakan bahwa DER ( Debt to Equity Ratio) berpengaruh signifikan terhadap harga saham. dinyatakan ditolak.

Perusahaan yang sebagian pengelolaannya dari hutang akan menyebabkan DER (Debt to Equity Ratio) yang tinggi. Karena semakin tinggi rasio DER (Debt to Equity Ratio) dapat memberikan sinyal buruk bagi investor, karena investor beranggapan bahwasannya 
perusahaan tersebut penuh dengan resiko. Akan tetapi, walaupun hasil dari DER (Debt to Equity Ratio) yang cukup tinggi pada perusahaan makanan dan minuman ini, rasio DER (Debt to Equity Ratio) tidak berpengaruh secara signifikan terhadap harga saham. Artinya disini para investor masih mempercayakan perusahaan tersebut untuk mengelola modalnya, walaupun rasio dari DER (Debt to Equity Ratio) termasuk cukup tinggi.

\section{SIMPULAN DAN SARAN}

\section{Simpulan}

Berdasarkan analisis dan pembahasan masalah diatas, maka dapat disimpulkan:

1) Variabel EPS (Earning Per Share) berpengaruh signifikan terhadap harga saham.

2) Variabel ROA (Return On Asset) berpengaruh signifikan terhadap harga saham.

3) Variabel DER (Debt to Equity Ratio) tidak berpengaruh signifikan terhadap harga saham.

\section{Saran}

1) Bagi perusahaan diharapkan lebih mengoptimalkan profitabilitas perusahaan dengan memperhatikan rasio ROA dan EPS yang dimiliki dalam mengelola keuangan perusahaan agar mampu meningkatkan return harga saham dengan meningkatkan laporan keuangan dan laba perusahaan. Serta lebih memperhatikan lagi rasio mengenai DER karena pada penelitian kali ini, peneliti menemukan tingginya rasio tersebut pada perusahaan makanan dan minuman yang terdaftar di BEI dari tahun 2015 sampai dengan tahun 2018.

2) Penelitian yang akan dilakukan selanjutnya supaya dapat menambahkan faktor-faktor lain yang mungkin berpengaruh terhadap Harga Saham perusahaan yang belum diteliti dalam penelitian ini.

3) Bagi investor harus memperhatikan macam-macam faktor yang dapat mempengaruhi harga saham untuk berinvestasi di perusahaan yang diinginkan. Dalam hal ini investor dapat melihat faktor-faktor yang terkait dalam perusahaan seperti EPS (Earning Per Share), ROA (Return On Asset), dan DER (Debt to Equity Ratio).

\section{Keterbatasan Penelitian}

Penelitian ini dilakukan dengan beberapa keterbatasan penelitian yang dengan keterbatasan tersebut dapat berpengaruh terhadap hasil penelitian. Keterbatasan-keterbatasan yang ada dalam penelitian ini adalah sebagai berikut: 
1) Penelitian ini terbatas hanya 4 tahun periode saja, yaitu pada tahun 2015 sampai dengan tahun 2018.

2) Penelitian ini hanya menggunakan data-data perusahaan yang berasal dari Indonesia, sehingga tidak dapat dibandingkan dengan negara-negara maju.

3) Penelitian ini hanya menguji 3 varibel saja, yaitu EPS (Earning Per Share), ROA (Retutrn On Asset), dan DER (Debt to Equity Ratio).

\section{DAFTAR PUSTAKA}

Adi, I. P., \& Lesmana, S. (2017). Manufaktur Yang Terdaftar Di Bursa Efek Indonesia Tahun 2012-2015. EJurnal Akuntansi Universitas Udayana, 19, 1060-1087.

Asri, M. H. (2017). Analisis Rasio Dengan Variabel Eps (Earning Per Share), Roa (Return on Assets), Roe (Return on Equity), Bopo (Biaya Operasional Pendapatan Operasional) Terhadap Harga Saham Perusahaan Perbankan. Jurnal Ilmiah Ekonomi Bisnis, 22(3), 275-287.

Datu, C. V., \& Maredesa, D. (2017). Pengaruh Devidend Per Share Dan Earning Per Share Terhadap Harga Sahampada Perusahaan Go Public Di Bursa Efek Indonesia. Going Concern: Jurnal Riset Akuntansi, 12(2), 1233-1242. https://doi.org/10.32400/gc.12.2.1869 6.2017

Dewi, M. D. W. (2018). Dan Dividen Terhadap Harga Saham ( Konsisten Terdaftar Lq45 Periode Tahun 20142016 ).
Efendi, F. M., \& Ngatno, N. (2018). Pengaruh Return On Assets (ROA Terhadap Harga Saham dengan Earning PerShare (EPS) sebagai Intervening (Studi Kasus pada Perusahaan Sub SektorTekstil dan Garmen yang terdaftar di Bursa Efek Indonesia Periode 2013-2016). Jurnal Administrasi Bisnis, 7(1), 1. https://doi.org/10.14710/jab.v7i1.225 68

Undang-Undang Republik Indonesia Nomor 21 Tahun 2008 Tentang Perbankan Syariah, OJK (2008). https://doi.org/10.1016/j.cell.2009.01. 043

Meyer, F. V., Corner, D. C., Parker, J. E. S., Meyer, F. V., Corner, D. C., \& Parker, J. E. S. (1970). Profitability. Problems of a Mature Economy, 5(1), 45-61. https://doi.org/10.1007/978-1-34915400-5_6

Nurfadillah, M. (2011). Analisis Pengaruh Earning Per Share, Debt To Equity Ratio Dan Return On Equity Terhadap Harga Saham Pt Unilever Indonesia Tbk. 12, 45-50.

Presiden Republik Indonesia, D. P. R. R. I. (DPRRI). (1995). Undang-Undang Republik Indonesia Nomor 8 Tahun 1995 Tentang Pasar Modal. Covering Globalization.

https://doi.org/10.7312/schi13174003

Priyatno, D. (2016). Cara kilat belajar analisis data dengan SPSS 20. Yogyakarta: Andi Offset.

Putra, F. E. P. E., \& Kindangen, P. (2016). Pengaruh Return on Asset (Roa), Net Profit Margin (Npm), Dan Earning Per Share (Eps) Terhadap Return Saham Perusahaan Makanan Dan Minuman Yang Terdaftar Di Bursa Efek Indonesia (Periode 2010-2014). 
Jurnal Riset Ekonomi, Manajemen, Bisnis Dan Akuntansi, 4(3), 235-245.

Setyorini, Maria, A. (2016). Pengaruh Return On Assets (Roa), Return On Equity (Roe), Dan Earning Per Share (Eps) Terhadap Harga Saham Perusahaan Real Estate Di Bursa Efek Indonesia (Studi Kasus pada 20 Perusahaan Periode 2011-2015). 2.

Suhadi, D. (2019). Pengaruh Rasio Aktivitas, Rasio Profitabilitas, Rasio Laverage, Dan Rasio Penilaian Terhadap Harga Saham Perusahaan Food and Beverage. Jurnal Informasi, Perpajakan, Akuntansi, Dan Keuangan Publik, 4(1), 17. https://doi.org/10.25105/jipak.v4i1.44 58

Watung, R., \& Ilat, V. (2016). Pengaruh Return on Asset (Roa), Net Profit Margin (Npm), Dan Earning Per Share (Eps) Terhadap Harga Saham Pada Perusahaan Perbankan Di Bursa Efek Indonesia Periode 2011-2015. Jurnal Riset Ekonomi, Manajemen, Bisnis Dan Akuntansi, 4(2), 518-529.

Winda Tristanti, \& Sari Marliani. (2019). Pengaruh Return on Equity Dan Earning Per Share Terhadap Harga Saham Pada Perusahaan Manufaktur Sub Sektor Makanan Dan Minuman Yang Terdaftar Di Bursa Efek Indonesia Periode 2012 - 2017. Buana Ilmu, 4(1), 116-136. https://doi.org/10.36805/bi.v4i1.813 